\title{
Analisis Kondisi Sosial Ekonomi Rumah Tangga Petani Tembakau di Desa Batu Nampar Kecamatan Jerowaru
}

\author{
Muhamad Zaril Gapari \\ STIT Palapa Nusantara \\ zagap205@yahoo.co.id
}

\begin{abstract}
Rural communities are communities that live in the same area, which are united and together, have strong ties and greatly influence one another. This is because the traditional village community is still very strong and thick. In general, village communities are identified with farming communities, this is because rural communities are predominantly making a living from agricultural products which are poor farmers whose livelihoods are below the poverty line. This shows a very large gap from urban communities. This study aims to determine the socioeconomic conditions of tobacco farm households in the village Batu Nampar Jerowaru District. The problem to be investigated is the effect of tobacco farming on the level of income of the farming community. This type of research is a descriptive study in which the population is 415 farm housebolds with a sample of 25 people using purposive sampling techniques. While the data collection techniques used in this study are direct interview techniques based on a list of questions that have been prepared previously. Based on the results of research and data analysis, the gross income of Rajang tobacco farmers is Rp. 90,230,000. the total cost spent by farmers during one growing season is Rp. 33,854,000 with an average of $\mathrm{R} p .1$ 1,354,000. Net income of Rajang tobacco farmers after deducting costs by Rp. 56,376,000 with an average income of Rp. 2,255,040. Judging from the indicators of welfare and based on the reference to the level of welfare from the three aspects measured namely housing, education, and health, the average respondent farmer is in the welfare category even though there are still some who are not yet prosperous. Where the pre-prosperous category is 7 people, prosperous I are 11 people, prosperous II is 5 people, prosperous III is 2 people and none of them have reached Prosperous III Plus.
\end{abstract}

Keywords: Social and Economic Conditions, Tobacco Farming Households

\begin{abstract}
Abstrak: Masyarakat desa adalah komunitas yang tinggal di dalam satu daerah yang sama, yang bersatu dan bersama-sama, memiliki ikatan yang kuat dan sangat mempengaruhi satu sama lain. Hal ini dikarenakan pada masyarakat desa tradisi itu masih sangat kuat dan kental. Pada umumnya masyarakat desa diidentikkan dengan masyarakat petani, ini dikarenakan masyarakat pedesaan dominan bermata pencaharian dari hasil pertanian yang merupakan petani-petani miskin yang mata pencahariannya di bawah garis kemiskinan. Hal ini menunjukkan kesenjangan yang sangat jauh dari masyarakat perkotaan. Penelitian ini bertujuan untuk mengetahui kondisi sosial ekonomi rumah tangga petani tembakau di Desa Batu Nampar
\end{abstract}

Islamika : Jurnal Keislaman dan Ilmu Pendidikan

Volume 2, Nomor 1, Januari 2020; 20-35

https:// ejournal.stitpn.ac.id/index.php/islamika 
Kecamatan Jerowaru. Adapun masalah yang akan diteliti adalah pengaruh usaha tani tembakau terhadap tingkat pendapatan masyarakat petani. Jenis penelitian ini adalah penelitian deskriptif dimana yang menjadi populasi adalah sebanyak 415 rumah tangga petani dengan sampel sebanyak 25 orang dengan menggunakan teknik purposive sampling. Sedangkan tekhnik pengumpulan data yang digunakan dalam penelitian ini adalah tekhnik wawancara langsung dengan berpedoman pada daftar pertanyaan yang telah disusun sebelumnya. Berdasarkan hasil penelitian dan analisis data yang dilakukan, diperoleh jumlah pendapatan kotor petani tembakau Rajang sebesar Rp. 90.230.000. total biaya yang dikeluarkan oleh petani selama satu musim tanam sebesar Rp. 33.854.000 dengan rata-rata sebesar Rp. 1.354.000. Pendapatan bersih petani tembakau Rajang setelah dikurangi biaya sebesar Rp. 56.376.000 dengan rata-rata pendapatan sebesar Rp. 2.255.040. Dilihat dari indikator kesejahteraan dan berdasarkan acuan tingkat kesejahteraan dari tiga aspek yang diukur yaitu perumahan, pendidikan, dan kesehatan, petani Responden rata-rata dalam kategori sejahtera meskipun masih ada yang belum sejahtera. Dimana kategori prasejahtera sebanyak 7 orang, sejahtera I sebanyak 11 orang, sejahtera II sebanyak 5 orang, sejahtera III sebanyak 2 orang dan belum ada yang sampai pada Sejahtera III Plus.

Kata Kunci: Kondisi Sosial ekonomi, Rumah Tangga Petani Tembakau

\section{PENDAHULUAN}

Masyarakat pedesaan di Indonesia tergolong masyarakat yang sangat jauh tertinggal, hal ini disebabkan keberadaan wilayah yang jauh dari pusat pembangunan Nasional. Beberapa metode dan pendekatan telah dikembangkan untuk memahami masalah dan membantu merumuskan kebijakan guna memecahkan masalah pembangunan pedesaan. Sejak tahun 1970-an para pakar banyak yang memanfaatkan metode, pendekatan, dan logika berfikir survey verifikatif dalam meriset masalah sosial masyarakat pedesaan. ${ }^{1}$

Pemberdayaan petani di pedesaan oleh pemerintah hampir selalu menggunakan pendekatan kelompok. Salah satu kelemahan yang mendasar adalah kegagalan pengembangan kelompok yang dimaksud, karena tidak dilakukan melalui proses sosial yang matang. Kelompok yang dibentuk terlihat hanya sebagai alat kelengkapan proyek, belum sebagai wadah untuk pemberdayaan kelompok tani secara menyeluruh.

Kelompok tani merupakan lembaga yang menyatukan para petani secara horizontal, dan dapat dibentuk beberapa unit dalam satu desa. Kelompok tani juga \begin{tabular}{llllll}
\hline${ }^{1}$ Chambers, Robert. $\quad$ "PRA & (Participatory & Rural & Appraisal) & Memahami & Desa \\
Secara Partisipatif”. (Yogyakarta: Penerbit Kanisuis, Tahun 1996), 1. & &
\end{tabular} 
dapat dibentuk berdasarkan komoditas, areal pertanian, dan gender. Pengembangan kelompok tani dilatarbelakangi oleh kenyataan kelemahan petani dalam mengakses berbagai kelembagaan layanan usaha, misalnya lemah terhadap lembaga keuangan, terhadap lembaga pemasaran, terhadap lembaga penyedia sarana produksi pertanian serta terhadap sumber informasi.

Berbagai kesalahan dalam pengembangan kelembagaan selama ini yaitu hampir tiap program pembangunan pertanian dan pengembangan masyarakat pedesaan membentuk satu kelembagaan yang baru. Sebagian besar kelembagaan dibentuk lebih untuk tujuan mendistribusikan bantuan dan memudahkan tugas kontrol bagi pelaksana program, bukan untuk pemberdayaan masyarakat secara nyata. Setiap program membuat satu organisasi yang baru dengan nama yang khas, jarang sekali program dari dinas tertentu menggunakan kelompok yang sudah ada. Pengembangan kelembagaan hanya dengan dukungan material yang cukup tapi tidak dibina bagaimana mengelolanya dengan manajemen yang baik. Walaupun kelembagaan telah dijadikan alat yang penting dalam menjalankan suatu program, namun penggunaan strategi pengembangan kelembagaan banyak mengalami ketidaktepatan dan kekeliruan. Secara konseptual tiap kelembagaan petani yang dibentuk dapat memainkan peran tunggal ataupun ganda. Khusus untuk kegiatan ekonomi, terdapat banyak lembaga pedesaan yang diarahkan sebagai lembaga ekonomi, diantaranya adalah kelompok tani, koperasi dan kelompok usaha agribisnis.

Secara konseptual masing-masing dapat menjalankan peran yang sama (tumpang tindih). Berdasarkan konsep sistem agribisnis, aktivitas pertanian pedesaan tidak akan keluar dari upaya untuk menyediakan sarana produksi (benih, pupuk dan obat-obatan), permodalan usahatani, pemenuhan tenaga kerja, kegiatan berusaha tani (on farm), pemenuhan informasi dan teknologi serta pengolahan dan pemasaran hasil pertanian.

Kawasan menunjuk pada suatu wilayah yang merupakan sentra (pusat), dapat berupa sentra produksi, perdagangan maupun sentra konsumsi. Dengan demikian kawasan sentra produksi tembakau adalah suatu kawasan pusat kegiatan produksi tembakau dalam suatu unit wilayah tertentu yang memiliki karakteristik yang relatif sama, dan memiliki kelengkapan infrastruktur dan sistem yang menunjang kegiatan produksi. 
Namun fakta yang kita temukan di lingkungan pertanian Desa bahwa infrastruktur yang dibutuhkan oleh para petani tidak memadai sehingga masalah pertanian di pedesaan begitu kompleks, baik masalah distribusi maupun produksi.

Batu Nampar adalah Desa kecil di Kecamatan Jerowaru Kabupaten Lombok Timur yang penduduknya adalah sebagian besar bermata pencaharian sebagai petani dan buruh tani. Masyarakat Desa Batu Nampar yang khususnya memiliki lahan pertanian yang tidak hanya menanam satu jenis tanaman saja namun berpariasi, mulai dari tanaman padi, tembakau, melon, kacang panjang, cabe dan lain-lain, namun lebih dominan masyarakat petani mengisi lahan pertaniannya dengan tanaman padi pada saat musim penghujan, tanaman tembakau dan cabe pada musim panas. Namun realita yang ada menunjukkan bawa tanaman tembakau biasanya dipadukan dengan tanaman cabe, hal ini bertujuan untuk mendapatkan keuntungan lebih. Tanaman tembakau yang biasa diproduksi oleh masyarakat setempat adalah tembakau biasa yang di open.

Hampir setengah dari jumlah petani rumah tangga memproduksi tanaman tembakau jenis ini, hal ini dikarenakan para petani beranggapan bahwa hasil yang diperoleh lebih banyak meskipun cara memproduksinya lebih membutuhkan tenaga dan waktu yang relatif panjang serta dapat meningkatkan tatanan sosial dan ekonominya. Disisi sosialnya masyarakat bermaksud untuk; 1) merubah kualitas perumahan tempat tinggal mereka, 2) meningkatkan kualitas pendidikan meraka serta dapat meningkatkan kualitas pendidikan keturunan mereka, 3) meningkatkan pemahaman terhadap pentingnya menjaga kesehatan. Dari sisi ekonomi masyarakat berharap dengan membudidayakan tanaman termbakau Rajang, pendapatan mereka meningkat sehingga dapat merubah kondisi sosial ekonomi mereka. Berdasarkan uraian di atas, maka dilakukan penelitian dengan judul "Kondisi Sosial Ekonomi Rumah Tangga Petani Tembakau di Desa Batu Nampar”.

\section{KAJIAN PUSTAKA}

\section{Rumah Tangga Petani Tembakau}

Petani pada umumnya dimaksud orang yang melakukan pertanian, akan tetapi bagaimana hubungan yang sebenarnya dengan pertanian itu tidaklah dijelaskan, bahkan terdapat banyak arti dari perkataan yang satu ini. Pada umumnya dengan 
istilah petani ini dimaksud semua orang penduduk pedesaan dalam arti "luar kota". Pertanian diartikan kegiatan melakukan pembukaan tanah dan menanaminya dengan berbagai jenis tanaman. ${ }^{2}$

Pertanian merupakan salah satu basis ekonomi kerakyatan di Indonesia. Pertanian pula yang menjadi penentu ketahanan, bahkan kedaulatan pangan. Tembakau (famili Solanaceae) merupakan salah satu dari enam komoditas terpenting di Indonesia. Sektor ini termasuk industri paling strategis yang dapat menyerap jutaan tenaga kerja, mulai dari petani tembakau, buruh atau pekerja pada perusahaan rokok, tenaga ahli, maupun pemasaran. Tembakau merupakan salah satu komoditas ekspor Indonesia yang cukup banyak mendatangkan devisa.

Dari penjelasan di atas dapat ditarik kesimpulan bahwa petani tembakau adalah orang yang melakukan kegiatan menanam jenis tanaman yang dapat mendatangkan keuntungan dan devisa bagi negera dari hasil ekspor.

\section{Perumahan}

Perumahan adalah kelompok rumah yang berfungsi sebagai lingkungan tempat tinggal atau hunian yang dilengkapi dengan prasarana lingkungan yaitu kelengkapan dasar fisik lingkungan, misalnya penyediaan air minum, pembuangan sampah, tersedianya listrik, telepon, jalan, yang memungkinkan lingkungan pemukiman berfungsi sebagaimana mestinya.

Rumah adalah tempat untuk melepaskan lelah, tempat bergaul, dan membina rasa kekeluargaan diantara anggota keluarga, tempat berlindung keluarga dan menyimpan barang berharga, dan rumah juga sebagai status lambang sosial. Rumah adalah struktur fisik terdiri dari ruangan, halaman dan area sekitarnya yang dipakai sebagai tempat tinggal dan sarana pembinaan keluarga. ${ }^{3}$

\section{Pendidikan}

Pendidikan adalah usaha sadar dan terencana untuk mewujudkan suasana belajar dan proses pembelajaran agar peserta didik secara aktif mengembangkan potensi dirinya untuk memiliki kekuatan spiritual keagamaan, pengendalian diri,

2 Adiwilaga, Anwas. 1982. Ilmu Usaha Tani. Bandung: Penerbit Alumni.

3Undang - Undang No 4 Tahun 1992. Tentang Perumahan dan Pemukiman. 
kepribadian dan kecerdasan, akhlak mulia, serta ketrampilan yang diperlukan dirinya, masyarakat bangsa dan negara. ${ }^{4}$

Penyelenggaraan pendidikan dilaksanakan melalui tiga jalur, yaitu jalur pendidkan formal, non formal dan informal. Jalur pendidikan formal merupakan pendidikan yang diselenggarakan di sekolah melalui kegiatan belajar mengajar secara berjenjang dan berkesinambungan. Jalur pendidikan non formal merupakan pendidikan yang diselenggarakan bagi warga masyarakat yang memerlukan layanan pendidikan yang berfungsi sebagai pengganti, penambah dan atau pelengkap pendidikan formal dalam rangka mendukung pendidikan sepanjang hayat. Sedangkan jalur pendidikan informal merupakan pendidikan yang diselenggarakan atau dilakukan oleh keluarga dan lingkungan berbentuk kegiatan belajar secara mandiri. ${ }^{5}$ Pendidikan yang dimaksud dalam penelitian ini adalah Pendidikan yang dimiliki para petani baik yang diperoleh melalui pendidikan formal, nonformal maupun yang diperoleh dari pendidikan informal.

\section{Kesehatan}

Kesehatan adalah keadaan seimbang yang dinamis, dipengaruhi faktor genetik lingkungan dan pola hidup sehari-hari seperti makan minum seks, kerja, istirahat, hingga pengelolaan kehidupan emosional. Satatus kesehatan tersebut menjadi rusak bila keadaan keseimbangan tergannggu, tetapi kebanyakan kerusakan pada periodeperiode awal bukanlah yang serius jika orang mau menyadarinya. ${ }^{6}$

Pendidikan kesehatan adalah proses membantu sesorang, dengan bertindak secara sendiri-sendiri ataupun secara kolektif, untuk membuat keputusan berdasarkan pengetahuan mengenai hal-hal yang memengaruhi kesehatan pribadinya dan orang lain.

\section{Pendapatan}

Pendapatan merupakan faktor yang sangat penting dalam menunjang perekonomian keluarga. Tingkat pendapatan merupakan salah satu indikasi sosial ekonomi seseorang di masyarakat disamping pekerjaan, kekayaan dan pendidikan.

${ }^{4}$ Undang-undang RI nomor 20 tahun 2003. Tentang Sistem Pendidikan Nasional, (Bandung : Fokus Media, 2006).

${ }^{5}$ Depdikbud. Perencanaan Pendidikan (Materi Pelatihan Calon Kepala Sekolah). (Jakarta: Dirjen Dikdasmen, Tahun 1999), 22.

${ }^{6}$ Santoso IA. Analisis dan perencangan sistem informasi rekam medis di rskia bhakti ibu. (Yogyakarta: STIMIK Amikom, Tahun 2012), 8. 
Pendapatan adalah jumlah penghasilan yang diterima oleh penduduk atas prestasi kerjanya selama satu periode tertentu, baik harian, mingguan, bulanan ataupun tahunan. $^{7}$

Pendapatan rumah petani pinggiran perkotaan juga bersumber dari tiga kegiatan utama, yaitu kegiatan dalam usaha tani sendiri (on-farm), kegiatan pertanian di luar usaha tani sendiri (off-farm) dan kegiatan di luar sektor pertanian (nonfarm). Untuk petani yang berada di pedesaan, pendapatan yang bersumber dari kegiatan onfarm dan off-farm umumnya mencapai lebih dari 90 persen. ${ }^{8}$

\section{Kesejahteraan}

Keluarga Sejahtera adalah Keluarga yang dibentuk berdasarkan perkawinan yang sah, mampu memenuhi kebutuhan hidup spiritual dan materi yang layak, bertaqwa kepada Tuhan Yang Maha Esa, memiliki hubungan yang selaras, serasi, dan seimbang antar anggota dan antar keluarga dengan masyarakat dan lingkungan".

Kesejahteraan keluarga tidak hanya menyangkut kemakmuran saja, melainkan juga harus secara keseluruhan sesuai dengan ketentraman yang berarti dengan kemampuan itulah dapat menuju keselamatan dan ketentraman hidup.

\section{METODE PENELITIAN}

Jenisnya penelitian ini adalah penelitian kuantitatif karena berhubungan dengan angka-angka, mulai dari pengumpulan data, penafsiran data, serta penampilan dari hasilnya. Dengan demikian jenis penelitian ini adalah penelitian deskriptif yang bertujuan untuk menggambarkan keadaan sosial ekonomi rumah tangga petani di Desa Batu Nampar Kecamatan Jerowaru.

Sampel adalah bagian dari jumlah dan karakteristik yang dimiliki oleh populasi tersebut. Bila populasi besar dan peneliti tidak mungkin mempelajari semua yang ada pada populasi, misalnya karena keterbatasan dana, tenaga dan waktu maka peneliti mengambil sampel yang diambil dari populasi. ${ }^{10}$

\footnotetext{
${ }^{7}$ Sukirno. Ekonomi Pembangunan, Proses Masalab dan Dasar Kebijakan. (Jakarta: Kencana Prenada Media Group, Tahun 2006), 47.

${ }^{8}$ Siregar, S. Sumber Daya Manusia (Konsep Universal Etos Kerja. (Jakarta: PT. Gramedia, Tahun 2000), 32. ${ }^{9}$ BKKBN. Pembangunan Keluarga Sejabtera di Indonesia Berdasarkan UU No. 10 Tabun 1992 dan GBHN tabun 1993. (Jakarta : Kantor Menteri Kependudukan/BKKBN, Tahun 1994), 5.

10 Sugiyono. Memahami Penelitian Kualitatif. (Bandung: CV. Alfabet, Tahun 2008), 81.
} 
Berdasarkan pendapat diatas maka dalam penelitian ini digunakan teknik sampel bertujuan atau purposive sampling. Teknik ini dilakukan karena beberapa pertimbangan yaitu keterbatasan waktu, tenaga, dan dana sehingga tidak dapat mengambil sampel yang besar dan jauh. Dengan demikian yang menjadi sampel dalam penelitian ini adalah sebagian dari jumlah populasi yang ada yaitu sebanyak 25 sampel, dimana sampel yang diambil memilik sifat dan karakteristik yang sama yang dapat mewakili populasi.

Dalam melakukan penelitian ini maka peneliti menggukan beberapa teknik dalam pengumpulan data antara kain:

Wawancara (interview) merupakan proses interaksi antara pewawancara dengan responden. ${ }^{11}$ Wawancara dilakukan oleh petani dengan menanyakan langsung kepada para petani atau narasumber yang lain sebagai subyek penlelitian. Observasi ialah pengamatan dan pencatatan yang sistematis terhadap gejala-gejala yang diteliti, observasi menjadi teknik pengumpulan data apabila: 1. sesuai dengan tujuan penelitian, 2. direncanakan dan dicatat secara sistematis, dan 3. dapat dikontrol kehandalannya/reliabilitasnya dan kesahihannya/validitas. ${ }^{12}$ Dari konsep tersebut, dapat disimpulkan bahwa observasi adalah pengamatan dan pencatatan secara sistematis terhadap gejala yang nampak pada objek dan subjek penelitian. Dokumen merupakan catatan peristiwa yang sudah berlalu. Dokumen bisa berbentuk tulisan, gambar atau karya-karya monumental dari seseorang. ${ }^{13}$ Adapun dokumentasi dalam penelitian ini adalah data profil Desa yang berasal dari instansi terkait yaitu Kantor Desa Batu Nampar Kecamatan Jerowaru.

Analisis data dalam penelitian merupakan suatu kegiatan penelitian yang sangat penting dan memerlukan ketelitian dan kekeritisan dari peneliti, analisis data merupakan proses mengolah dan mengadakan pengkajian terhadap data-data yang telah didapatkan dari lapangan, baik dari wawancara, observasi, dokumentsi, dan sumber-sumber lainnya. ${ }^{14}$ Tekhnik analisis data dipergunakan untuk mengetahui

\footnotetext{
${ }^{11}$ Nazir,M. Metode Penelitian. (Jakarta : Ghalia Indonesia, Tahun 2003), 194.

12 Usman, Husnaini. Metodologi Penelitian Sosial. (Jakarta: Bumi Aksara, Tahun 2004), 54.

${ }^{13}$ Sugiyono. Metode Penelitian Kuantitatif, Kualitatif dan R\&D, (Bandung : Alfabeta, Tahun 2009), 240.

${ }^{14}$ Zuriah, Nurul.. Pendidikan Moral dan Budi Pekerti dalam Perspektif Perubahan Mengagas platform Pendidikan Budi Pekerti secara Kontekstual dan futuristik. (Jakarta: PT Bumi Aksara, Tahun 2007).
} 
kodisi sosial ekonomi masyarakat rumah tangga petani tembakau yang ada di Desa Batu Nampar Kecamatan Jerowaru.

Untuk mengetahui pendapatan bersih dari rumah tangga petani tembakau adalah dengan menggunakan rumus sebagai berikut. ${ }^{15}$

Rumus : NR $=$ TR-TC

Dimana :

NR : Pendapatan bersih yang diterima oleh RT Petani

TR : Pendapatan kotor yang diterima oleh RT Petani

TC : Total biaya yang dikeluarkan oleh rumah tangga Petani

Adapun untuk mengukur sosial ekonomi masyarakat dengan mengukur tingkat kesejahteraan masyarakat.

Menurut BKKBN Lombok Timur Tahun 2007, ada 4 tahapan kesejahteraan masyarakat yaitu: Keluarga Sejahtera I, Kelurga Sejahtera II, Keluarga Sejahtera III, dan Kelurga Sejahtera III Plus.

\section{HASIL PENELITIAN}

\section{Karakteristik Responden}

Dalam penelitian ini karakteristik rumah tangga adalah gambaran tentang identitas petani yaitu: Pendidikan, umur dan Jumlah Tanggungannya.

a. Pendidikan

Tabel Jumlah Responden Pada Usaha Tani Tembakau Berdasarkan tingkat

Pendidikan di Desa Batu Nampar Kecamatan Jerowaru Tahun 2019

\begin{tabular}{|c|c|c|c|}
\hline No & Tingkat pendidikan & Jumlah & Persentase (\%) \\
\hline 1 & Tidak Pernah Sekolah & - & - \\
\hline 2 & SD (Sekolah Dasar) & 9 & $36 \%$ \\
\hline 3 & Sekolah Menengah Pertama (SMP) & 10 & $40 \%$ \\
\hline 4 & Sekolah Menengah Atas (SMA) & 4 & $16 \%$ \\
\hline 5 & Diploma / Sarjana & 2 & $8 \%$ \\
\hline \multicolumn{2}{|c|}{ Jumlah } & 25 & $100 \%$ \\
\hline
\end{tabular}

${ }^{15}$ Boediono. Ekonomi Moneter Edisi 3. Yogyakarta: BPFE, Tahun 2008), 27. 
b. Tingkat Umur

Tabel. Jumlah Responden Pada Usaha Tani Tembakau Berdasarkan

Kelompok Umur di Desa Batu Nampar Kecamatan Jerowaru Tahun 2019

\begin{tabular}{|c|c|c|c|}
\hline No & Umur (Tahun) & Jumlah & Persentase (\%) \\
\hline 1 & $25-30$ & 1 & $4 \%$ \\
\hline 2 & $31-36$ & 5 & $20 \%$ \\
\hline 3 & $37-42$ & 5 & $32 \%$ \\
\hline 4 & $43-48$ & 3 & $12 \%$ \\
\hline 5 & $49-54$ & 4 & $16 \%$ \\
\hline 6 & $55-60$ & 3 & $12 \%$ \\
\hline 7 & $61-66$ & 1 & $4 \%$ \\
\hline \multicolumn{2}{|c|}{ Jumlah } & 25 & $100 \%$ \\
\hline
\end{tabular}

c. Jumlah Tanggungan

Table Nama Responden dan Jumlah Tanggungan

di Desa Batu Nampar Kecamatan Jerowaru Tahun 2019

\begin{tabular}{|c|c|c|c|}
\hline No & Kisaran Orang & Jumlah Orang & Persentase (\%) \\
\hline 1 & $3-4$ & 10 & $40 \%$ \\
\hline 2 & $5-6$ & 12 & $48 \%$ \\
\hline 3 & $7-8$ & 3 & $12 \%$ \\
\hline \multicolumn{2}{|c|}{ Jumlah } & 25 & $100 \%$ \\
\hline
\end{tabular}

\section{Deskripsi Data}

Adapun deskripsi data dalam penelitian ini adalah sebagai berikut:

a. Jenis Pekerjaan petani responden

Tabel Jumlah Responden Pada Usaha Tani Tembakau Berdasarkan Jenis Pekerjaan di Desa Batu Nampar Kecamatan Jerowaru Tahun 2019

\begin{tabular}{|c|c|c|c|c|}
\hline No & Jenis Pekerjaan & Nama Pekerjaan & Jumlah & Persentase \\
\hline 1 & Pekerjaan Utama & Petani & 25 & $100 \%$ \\
\hline & & Nelayan & 1 & $4 \%$ \\
\hline
\end{tabular}




\begin{tabular}{|c|c|c|c|c|}
\hline \multirow{3}{*}{2} & \multirow{3}{*}{$\begin{array}{c}\text { Pekerjaan } \\
\text { Sampingan }\end{array}$} & Pedagang & 3 & $12 \%$ \\
\cline { 3 - 5 } & \multirow{2}{*}{3} & Ojek & 3 & $12 \%$ \\
\cline { 3 - 5 } & & Buruh Tani & 8 & $32 \%$ \\
\cline { 3 - 5 } & Tukang Bangunan & 3 & $12 \%$ \\
\hline 3 & Tidak memiliki pekerjaan sampingan & 7 & $28 \%$ \\
\hline
\end{tabular}

b. Biaya-biaya Produksi Usaha Tani Tembakau

Tabel Total Biaya Yang Dikeluarkan Oleh Responden

di Desa Batu Nampar Kecamatan Jerowaru Tahun 2019

\begin{tabular}{|c|l|c|c|}
\hline No & \multicolumn{1}{|c|}{ Keterangan } & $\begin{array}{c}\text { Besar biaya } \\
(\mathrm{Rp})\end{array}$ & $\begin{array}{c}\text { Rata-Rata } \\
(\mathrm{Rp})\end{array}$ \\
\hline 1 & Biaya Pembibitan & 6.120 .000 & 244.800 \\
\hline 2 & \multicolumn{2}{|l|}{ Biaya Tenaga Kerja } \\
\cline { 2 - 4 } & $\begin{array}{l}\text { Pencangkulan / } \\
\text { pengolahan tanah }\end{array}$ & 5.790 .000 & 231.600 \\
\cline { 2 - 4 } & Biaya penanaman & 2.680 .000 & 107.200 \\
\cline { 2 - 4 } & Biaya perawatan & 3.850 .000 & 154.000 \\
\hline 3 & Biaya Pemupukan & 10.720 .000 & 428.800 \\
\hline 4 & Biaya Pemetikan & 1.280 .000 & 51.200 \\
\hline 5 & Biaya Transfortasi & 859.000 & 34.360 \\
\hline 6 & Biaya Pengopenan & 1.870 .000 & 74.800 \\
\hline 7 & Biaya Ngebil & 685.000 & 27.400 \\
\hline \multicolumn{2}{|c|}{ Jumlah } & 33.854 .000 & 1.354 .000 \\
\hline
\end{tabular}

c. Pendapatan

Tabel Total pendapatan utama dan sampingan Petani Responden

di Desa Batu Nampar Kecamatan Jerowaru Tahun 2019

\begin{tabular}{|c|c|c|c|}
\hline No & Keterangan & $\begin{array}{c}\text { Total Pendapatan } \\
(\mathrm{Rp})\end{array}$ & $\begin{array}{c}\text { Rata-rata } \\
(\mathrm{Rp})\end{array}$ \\
\hline 1 & Pendapatan Utama & 90.230 .000 & 3.609 .200 \\
\hline 2 & Pendapatan Sampingan & 3.990 .000 & 159.600 \\
\hline
\end{tabular}




\begin{tabular}{|c|c|c|}
\hline Jumlah & 94.220 .999 & 3.768 .800 \\
\hline
\end{tabular}

\section{Hasil Analisis Data}

a. Analisis Tingkat Pendapatan Responden

Dari hasil wawancara dan analisis yang dilakukan terhadap 25 petani responden dapat diperoleh pendapatan utama sebesar Rp.90.230.000 dan pendapatan sampingan sebesar Rp.3.990.000 dengan total biaya yang dikeluarkan petani responden sebesar Rp.33.854.000 sehingga untuk mengetahui pendapatan bersih responden dapat ditentukan dengan rumus sebagai berikut :

Berdasarkan Rumusnya, maka dapat dicari pendapatan bersih petani responden sebagai berikut:

$$
\begin{aligned}
& \mathrm{NR}=\mathrm{TR}-\mathrm{TC} \\
& \mathrm{NR}=94.220 .999-33.854 .000 \\
& \mathrm{NR}=60.366 .000
\end{aligned}
$$

Dari penghitungan rumus tersebut dapat ditentukan pendapatan bersih petani responden Desa Penedagandor Kecamatan Labhan Haji yaitu sebesar Rp. 60.366.000 dengan pendapatan rata-rata sebesar Rp. 2.414.640 dapat dinyatakan dalam tabel sebagai berikut :

Tabel Total Pendapatan Kotor, Total Pendapatan Bersih dan pendapatan rata-rata Petani Responden

di Desa Batu Nampar Kecamatan Jerowaru Tahun 2019

\begin{tabular}{|c|l|c|}
\hline No & \multicolumn{1}{|c|}{ Keterangan } & Total Pendapatan (Rp) \\
\hline 1 & Pendapatan Kotor & 94.220 .999 \\
\hline 2 & Pendapatan Bersih & 60.366 .000 \\
\hline 3 & Pendapatan Rata-Rata & 2.414 .640 \\
\hline
\end{tabular}

Berdasarkan tabel di atas dapat disimpulkan bahwa pendapatan bersih masyarakat petani cukup untuk memenuhi kebutuhan sehari-hari dengan pendapatan bersih rata-rata sebesar Rp.2.255.040.

b. Analisis Tingkat Kesejahteraan Responden

Selain faktor pendapatan diatas, ada beberapa kondisi yang perlu dianalisis sebagai acuan dalam menarik sebuah kesimpulan untuk menyatakan kondisi sosial 
masyarakat Desa Batu Nampar, terutama kondisi pendidikan, kesehatan dan perumahannya. kondisi tersebut dapat diukur dengan indikator kesejahteraan. Untuk lebih jelasnya dapat dilihat pada ditabel sebagai berikut:

Tabel Rekapitulasi Tingkat Kesejahteraan Rumah Tangga Petani

Desa Batu Nampar Kecamatan Jerowaru Tahun 2019

\begin{tabular}{|c|l|c|c|}
\hline No & \multicolumn{1}{|c|}{ Tingkatan } & Jumlah (Orang) & Persentase (\%) \\
\hline 1 & Prasejahtera & 7 & 28 \\
\hline 2 & Prasejahtera I & 11 & 44 \\
\hline 3 & Prasejahtera II & 5 & 20 \\
\hline 4 & Prasejahtera III & 2 & 8 \\
\hline \multicolumn{2}{|c|}{ Jumlah } & 25 & 100 \\
\hline
\end{tabular}

Berdasarkan Tabel diatas dapat dijelaskan bahwa, Petani yang termasuk keluarga prasejahtera sebanyak 7 orang dengan persentase sebesar $28 \%$, yang termasuk sejahtera I sebanyak 11 orang, termasuk sejahtera II sebanyak 5 orang dan termasuk sejahtera III sebanyak 2 orang. Hal ini berarti bahwa Rumah tangga Petani Desa Batu Nampar Kecamatan Jerowaru Kabupaten Lombok Timur Tahun 2019 rata-rata dalam kondisi sejahtera, meskipun ada sebagian kecil rumah tangga Petani yang belum sejahtera.

\section{PEMBAHASAN}

Sebagian besar rumah tangga petani mengandalkan hasil tanah/pertanian untuk memenuhi kebutuhan sehari-hari, karna pendapatan rumah tangga sebagian besar dihasilkan dari pertanian. Hal ini berdasarkan hasil analisis dan perhitungan yang diakukan peneliti yaitu mencari pendapatan bersih petani dengan menentukan pendapatan kotor yaitu dengan menjumlahkan pendapatan utama dengan pendapatan sampingan kemudian dikurangi dengan besarnya biaya-biaya yang dikeluarkan selama musim tanam.

Diketahui biaya yang dikeluarkan petani selama musim tanam adalah Rp. 33.854 .000 dan pendapatan kotor (pendapatan utama sebesar Rp. 90.230 .000 + pendapatan sampingan sebesar Rp 3.990.000) sehingga diperoleh pendapatan kotor sebesar Rp. 
94.220.999. Setelah dilakukan perhitungan, jumlah pendapatan bersih petani responden adalah Rp. 60.366.000 dengan rata-rata Rp. 2.414.640.

Jika dilihat dari kondisi sosial rumah tangga petani yaitu pendidikan anggota rumah tangga petani umus 7-15 tahun dapat mengeyam pendidikan hal ini dikarenakan kesadaran mereka terhadap pentingnya pendidikan dan cita-cita masyarakat rumah tangga petani untuk meningkatkan mutu dan kualitas sumber daya yang mereka miliki. Dilihat dari segi permahan atau tempat tinggal rumah tangga petani dapat disimpulkan bahwa kondisi perumahan dari atap, lantai dan dinding dalam kondisi bagus atau layak huni. Hanya saja ukuran rumah responden masih banyak yang kurang dari $8 \mathrm{~m}^{2}$ sehingga tidak mencapai sejahtera II hanya sampai sejahtera I. Dari segi kesehatan petani responden disimpulkan bahwa petani tembakau Desa Batu Nampar sejahtera dimana hasil wawancara dan penuturan petani menyatakan selama 3 bulan terakhir jarang sekali ada angota keluarga yang jatuh sakit, kalaupun ada yang sakit langsung dibawa ke puskesmas atau peraktikan yang menyediakan jasa kesehatan medis.

Berdasarkan acuan tingkat kesejahteraan dari tiga aspek yang diukur yaitu perumahan, pendidikan, dan kesehatan, petani Responden rata-rata dalam kategori sejahtera meskipun masih ada yang belum sejahtera. Dimana kategori prasejahtera sebanyak 7 orang dengan persentase $28 \%$, sejahtera I sebanyak 11 orang dengan persentase $44 \%$, sejahtera II sebanyak 5 orang dengan persentase $20 \%$ dan sejahtera III sebanyak 2 orang dengan persentase 8\%. Dengan demikian tingkat kesejahteraan petani sebagian besar berada pada kategori sejahtera I.

\section{KESIMPULAN}

Berdasarkan hasil analisis data yang telah dilakukan maka dapat ditarik kesimpulan bahwa kondisi sosial ekonomi rumah tangga petani tembakau berdasarkan indikator yang digunakan adalah.

1. Perumahan

Perumahan atau tempat tinggal Petani Desa Batu Nampar Kecamatan Jerowaru dapat disimpulkan bahwa kondisi perumahan dari atap, lantai dan dinding dalam kondisi bagus atau layak huni. Hanya saja ukuran rumah responden masih 
banyak yang kurang dari $8 \mathrm{~m}^{2}$ sehingga tidak mencapai sejahtera II hanya sampai sejahtera I.

2. Pendidikan

Pendidikan petani tembakau Rajang rata-rata berpendidikan meskipun ada 2 responden yang tidak pernah mengenyam pendidikan dan sebagian besar anggota rumah tangga petani umur 7-15 tahun dalam usia sekolah sebanyak 22 orang, hal ini menunjukkan bahwa kepedulian mereka terhadap pendidikan sangat tinggi.

3. Kesehatan

Dilihat dari segi kesehatan petani responden disimpulkan bahwa petani tembakau Rajang Desa Batu Nampar Kecamatan Jerowaru sejahtera dimana hasil wawancara dan penuturan petani menyatakan selama 3 bulan terakhir jarang sekali ada angota keluarga yang jatuh sakit, kalaupun ada yang sakit langsung dibawa ke puskesmas atau peraktikan yang menyediakan jasa kesehatan medis.

4. Total pendapatan bersih rumah tangga petani Desa Batu Nampar Kecamatan Jerowaru Tahun 2019 adalah Rp. 60.366.000 pada satu musim tanam tembakau, dengan rata-rata pendapatan yaitu Rp. 2.414.640.

Sehingga dari keseluruhan indikator kesejahteraan dapat disimpulkan bahwa masyarakat petani Desa Batu Nampar Kecamatan Jerowaru Tahun 2019 yang anggota keluarganya tergolong prasejahtera sebanyak 7 orang, sejahtera I sebanyak 11 orang, sejahtera II sebanyak 5 orang dan sejahtera III sebanyak 2 orang.

\section{SARAN}

Berdasarkan hasil penelitian dan terbatas pada permasalahn yang timbul dalam penelitian ini maka diajukan saran sebagai berikut :

1. Diharapkan kepada masyarakat petani agar hasil pertanian tembakau dengan menggunakan faktor-faktor produksi secara efisien dan mencari pekerjaan sampingan di waktu luang guna meningkatkan kualitas perekonomian.

2. Diharapkan kepada masyarakat Petani untuk lebih memperhatikan dan mengutamakan pendidikan dalam membudidayakan usaha tani tembakau agar kualitas tembakau yang dapat meningkatkan hasil pertaniannya dan memberikan kesempatan bagi putra putrinya mengenyam pendidikan yang lebih tinggi agar 
mampu merubah tatanan hidup menjadi lebih baik serta mampu merubah sistem pertanian tradisional ke sistem pertanian modern.

3. Kesehatan juga lebih dijaga agar rumah tangga Petani bisa bekerja dengan baik, tanpa harus terhalangi oleh penyakit.

4. Rumah tangga petani Desa Batu Nampar Kecamatan Jerowaru juga perlu memperbaiki kondisi perumahannya agar layak untuk ditempati baik dari segi atap, lantai dan dinding. Agar bisa mencapai keluarga yang sejahtera.

5. Diharapkan juga kepada pemerintah setempat agar lebih memperhatikan para petani dengan cara memberikan bantuan berupa modal maupun pelatihan agar bisa mengembangkan usahanya.

\section{DAFTAR PUSTAKA}

Anwas, Adiwilaga. 1982. Imu Usaha Tani. Bandung: Penerbit Alumni

BKKBN. 1994 Pembangunan Keluarga Sejabtera di Indonesia Berdasarkan UU No. 10 Tabun 1992 dan GBHN tabun 1993. Jakarta : Kantor Menteri Kependudukan/BKKBN.

Boediono. 2008. Ekonomi Moneter Edisi 3. Yogyakarta: BPFE.

Chambers, Robert. 1996. "PRA (Participatory Rural Appraisal) Memahami Desa Secara Partisipatif”. Yogyakarta: Penerbit Kanisuis.

Depdikbud. (1999). Perencanaan Pendidikan (Materi Pelatihan Calon Kepala Sekolah). Jakarta: Dirjen Dikdasmen.

Nazir,M. 2003. Metode Penelitian. Jakarta : Ghalia Indonesia.

Santoso IA, 2012. Analisis dan perencangan sistem informasi rekam medis di rskia bhakti ibu. Yogyakarta: STIMIK Amikom.

Sugiyono. 2008. Memahami Penelitian Kualitatif. Bandung: CV. Alfabeta. -, 2009, Metode Penelitian Kuantitatif, Kualitatif dan R\&D, Bandung : Alfabeta.

Sukirno, S. 2006. Ekonomi Pembangunan, Proses Masalah dan Dasar Kebijakan. Jakarta: Kencana Prenada Media Group.

Undang - Undang No 4 Tahun 1992 tentang Perumahan dan Pemukiman

Undang-undang RI nomor 20 tahun 2003 tentang Sistem Pendidikan Nasional, (Bandung : Fokus Media, 2006

Usman, Husnaini. 2004. Metodologi Penelitian Sosial. Jakarta: Bumi Aksara.

Zuriah, Nurul. 2007. Pendidikan Moral dan Budi Pekerti dalam Perspektif Perubahan Mengagas platform Pendidikan Budi Pekerti secara Kontekstual dan futuristik. Jakarta: PT Bumi Aksara. 